\title{
Education of Children in Times of Conflict: A Study of Atoizu in Nagaland
}

Tiatula Ozukum is presently teaching at the Department of Sociology, St. Joseph University, Dimapur. She has worked extensively on topics related toSocial Capital, Naga Traditional Institutions, Communitisation of Elementary Education, Conflict and Tribal Sociology.

\section{Abstract}

Research interest on education in conflict and post conflict zones is gaining prominence across the world. There has been an increased academic attention on how children access education, how schools function, what kind of knowledge is transmitted in areas where there has been conflict. Hence, it is an undenying fact that conflict can interrupt education through the destruction of schools, targeting of teachers, the increase of fear and insecurity etc. Within such kind of a background, the study aimed to capture the micro experiences of community, students and teachers in a small hill town of Atoizu in district of Zunheboto in Nagaland. The study took students and teachers as primary sources of data as they are the ones who get or may have got affected by the conflicts in such a zone of conflict.

Keywords: Children, Education, Conflict, Atoizu, Knowledge Transmission.

If we examine centuries of human history, we find that conflict has been a salient aspect of the very human experience. Conflicts have existed among and between nations, among various cultural and ethnic groups, in dyadic relationships and within individuals. Efforts to resolve, rise above and transform conflict have been met with a myriad challenges. ${ }^{1}$ Conflicts have multiple forms, characteristics and impacts on the society. Much of today's conflicts between societies, groups and individuals have their roots in some 


\section{6 /Tiatula Ozukum}

Salesian Journal of Humanities and Social Sciences, Vol. X, No. 1. (May 2019) ISSN: 0976-1861 | DOI: 10.51818/SJHSS.10.2019.35-45 | Page: 35-45,

Section: Article

kind of identity or primordial affiliation such as, caste, religious community, ethnicity, or sub-nationalities. It is these conflicts that disrupt the everyday functioning of societies of today. The identity based conflicts primarily arise due to the perceived supremacy of one group over the other or the perceived claims of rights and privileges of one over the other which lead to constant bickering and tensions. Not only that, the very structures of multi-ethnic, multicaste, multi-community social settings are deeply hierarchical too, which often position two groups, one in a position of dominance and the other in subjugation. Such contradictions in social order thus gives rise to perpetual bickering and disruptions within the social fabric, collective social life and access to opportunities such as health, education, etc.

As conflicts continue to plague societies of today, research interest on studying such conflicts has also increased within social sciences. According to Paulson, 'education and conflict have become a new and expanding area of specialization for academics, policy makers and development agency staff' ${ }^{2}$ She maintains that since the mid1990s a growing body of literature and research has emerged on 'education and conflict' and on 'emergency education'. Brannelly et al also strongly argue that the educational needs of children affected by conflict, emergencies and fragility have become an area of increasing attention. This is because millions of children are denied the right to education across the world and it is estimated that over half of the world's out of school children live in fragile and conflict- affected states. ${ }^{3}$ In India, however, this theme has not received much attention though the country has been witnessing conflicts of various kinds ever since Independence. The conflict in Nagaland, and other North East states, is as old as the Indian Independence itself though there have been periods of low intensity conflict in all these six odd decades.

2 Julia Paulson, "(Re)creating Education in Post conflict Contexts: Transitional Justice, Education and Human Development", (Research Unit, International Center for Transitional Justice, November, 2009), 5.

${ }^{3}$ Laura Brannelly, et al., “Donor's Engagement: Supporting Education in Fragile and Conflict Effected States", (UNESCO 2009), 23. 
It may be noted that each conflict and post conflict situation is different from the other, with regard to histories and conditions, including the duration of the conflict, the number of persons involved, the intensity of violence, etc. With this backdrop in mind, the paper examines and documents the effects of conflict on schooling, particularly with reference to the state of Nagaland which is seen as one of the oldest zone of insurgent armed conflict and violence. The main purpose of the study is to focus on understanding how conflict disrupts social life and also the schooling, what kind of experiences children and teachers undergo during times of conflict.

\section{Origin and Nature of Conflict in Atoizu}

Atoizu is a small hill town located under Zunheboto District of Nagaland. It has at present around 800 households with a population of approximately 3500. The town has been witnessing conflict between different factional groups in Nagaland since the early 1990s. Conflict has often led to the disruption of life and schooling in the town and has often gone unrecorded as it is slightly remote. The nature of conflict post 2008 has been sporadic and of low intensity. Skirmishes and contesting battles have been a common place in the town at regular intervals in the past. However, Atoizu still remains a sensitive area, where clashes between warring militant factions can commence anytime. Though situation has improved in the recent past with lesser number of clashes, yet there is no guarantee that conflict in this town has ended and will not happen again in the future. For instance, it was noted during the fieldwork that the most recent act of violence and militant activity took place as recently as in the year 2015. It is clear from the responses from the community that the town and its citizens bear the brunt of the armed conflict over the years. Its citizens, especially the children and youth, live in constant fear and with suspicion that there could be gunfire at any moment. The chances of encountering such a situation loom large thereby instilling a sense of perpetual fear among the people.

When factional clashes occur, everyday life comes to a standstill and often results in loss of life and property of the general public as well. Moreover, the possibility of conflict between factional groups 


\section{8 /Tiatula Ozukum}

Salesian Journal of Humanities and Social Sciences, Vol. X, No. 1. (May 2019) ISSN: 0976-1861 | DOI: 10.51818/SJHSS.10.2019.35-45 | Page: 35-45,

Section: Article

plays havoc with the lives of the people of whom the most affected are the students. It affects the daily life and functioning of people and institutions especially schools where daily attendance is important. With schools closing due to conflict every now and then the state of education and schools in the area is abysmal. The following discussion thus attempts to explore deeper into understanding how conflict disrupts schooling.

\section{Disruption and Impact of Conflict on Schooling}

There can be many reasons as to why a child, living in an area which is prone to conflict, may attend school irregularly or sometimes not at all. Lynn Davies argues that there are long-term effects on the staffing and governance of education in times of conflict. Seitz argues that millions of children are prevented from attending schools as a consequence of violent conflict. UNESCO also reports that education is a right protected by the Universal Declaration of Human Rights, but over 28 Million children around the world are out of school and are denied an education as a result of the civil conflict. This section locates the experiences of children and teachers on how sudden outbreak of conflict disrupted the schooling process in Atoizu.

\section{Destruction of School and College Buildings and Infrastructure}

Like in any other society where conflict occurs frequently, so too in Atoizu, the destruction of educational infrastructure is an inevitable consequence. Wessel and Hirtum in their study, 'Children on War', point out that in many instances the troops made schools their base camps because there they have bigger rooms, a lot of space, grounds, etc. ${ }^{4}$ In the case of Atoizu, the experiences of a respondent whose hostel building was damaged during crossfire between two groups are worth noting:

In the year 2006, one of the factional groups was settled down at our college building and the other group was settled down at one of

${ }^{4}$ Margit Van Wessel and Ruud Van Hirtum "Schools as Tactical Targets in Conflict: What the Case of Nepal Can teach us" Comparative Education Review, vol. 57, no. 1, (2013): 9. 
the boys' hostels. During that time clash broke out between the two groups. As the situation was so tensed we decided to go back to our own homes as the factional cadres would not leave our hostel. The next firing incident happened when we were all back at our home town. I do not know the details of the incident as I was at my home town that time. However, when I returned to Atoizu after the situation subsided, the firing between the two groups was so intense that the hostel had bullet marks all over the building. ${ }^{5}$

Another respondent describes,

There was this particular incident where the NSCN (IM) and the NSCN (K) were engaged in cross-fire. It was in the middle of the year 2008, where the NSCN (K) soldiers were firing from the hilly area just behind our hostel. During this time the windowpanes of our hostel got shattered by the bullets fired by one of the groups. The hostel even had bullet marks on the first floor of the building. ${ }^{6}$

As highlighted in the above narratives, the educational institutions including the hostels often serve as the base camps or resting place of various factional groups. It may be inferred from the respondents that not only are the school buildings and hostels used as base camps but there are several instances where firing had happened while the insurgent groups were stationed in the buildings. As a result, it phyiscally damages the instituion during the crossfire in real terms and serves as a constant reminder of the turmoil they underwent. The insecurity, tension and physical dangers faced by the children is enormous and has dramatic consequences on their later life.

\section{Sudden Outbreak of Conflict}

There is an element of suddenness in the happenings of armed conflict and children get affected when these incidents happen during the school time. During the course of discussion, a respondent recollected an incident:

\footnotetext{
${ }^{5}$ Asung (Ex-student, KPA) in discussion with the author, December 11, 2011.

${ }^{6}$ Mathang, in discussion with the author, December 15, 2011.
} 


\section{0 /Tiatula Ozukum}

Salesian Journal of Humanities and Social Sciences, Vol. X, No. 1. (May 2019) ISSN: 0976-1861 | DOI: 10.51818/SJHSS.10.2019.35-45 | Page: 35-45,

Section: Article

When I was in class VI, firing between two groups broke out during the middle of our class. There were gunshots at the vicinity of the area. So as usual we were made to hide under our own desks by our teacher. The gunshots went on for about 30 minutes, and until the situation came to normal we had to stay under the desks. That day our class was dismissed and we were sent home after our parents came to pick us up from our respective classes. ${ }^{7}$

In Atoizu, there have been several instances where the cross-firing between the insurgent groups led to disturbances in the normal functioning of the schools and colleges. There is certain abruptness about armed conflict and it affects the children especially when it happens during the class hours. This is very clear from the several instances narrated by the students. One of the most commonly stated experience of students was how during class hours due to cross firing, they had to get down under the classroom benches and lay low on the ground. On certain occasions they even had to crawl out of the classrooms to safer places at the school.

In such conditions, institutions, especially schools, are urgently shut down. With no prior and proper information, the schools remain closed until situation returns to normalcy. The days when the situation is dangerous the classes are held irregularly or schools remain closed and consequently the syllabi remain unfinished. The mounting tension results in creating situations which are not conducive to learning or for other curricular activities. The scarce and erratic means of communication further impedes dissemination of information about classes. Hence, many students are left at sea over what the next course of action will be.

\section{Physical Obstacles Faced by Students and Teachers}

Various studies show that violent conflict leads not only to loss of lives but also causes physical trauma among children, teachers, parents, siblings and community members either directly as targets of war or indirectly as victims in the crossfire. ${ }^{8}$ Seitz points out the

${ }^{7}$ (Local student, Adelfos School) in discussion with the author, May 18, 2015.

${ }^{8}$ See: Peter Buckland, Reshaping the Future: Education and Post Conflict Reconstruction. 
fact that schools, and with them children, teachers and parents, can become direct targets of violent conflicts. A respondent narrates his experiences of the obstacles he had to face whenever conflict in the area became severe.

The firing was quite severe that day, the students in the town started fleeing to the nearby town and villages. This was the time when I along with four other hostellers also decided to flee to a safer place. Since there was no proper transportation, we went to the next town on foot. We walked for $16 \mathrm{kms}$ without stopping that day. The locals told us not to go and asked us to join the community in stopping the factional groups from firing at each other but who will risk their lives on that. We decided not to listen to them and continued our journey. After we reached the next town, we somehow managed to stop the trucks plying towards our home town and we reached home. We returned to the institute only after a week once the firing subsided. ${ }^{9}$

He further added that there were a lot of similar incidents that had caused obstacles to their normal life as a student. Fleeing to a safer place when there was conflict thus depended on the intensity of conflict in the area. He maintained that in his three years of stay as a student in the town, he had to flee to the nearest town in search for safety 4-5 times. During various flights from dangers of conflict, communities as well as children get exposed to numerous physical dangers. They can be threatened by sudden attacks out of nowhere on the way, and often end up walking for several hours crossing several miles until they find a place which they think would be safe and secure for them.

\section{Trauma, Insecurities and long-term Psychological Effects}

Armed conflict affects all aspects of child development-physical, mental and emotional. Historically those concerned with the

(Washington DC: The International Bank for Reconstruction and Development/ World Bank, 2005), Graca Machel, "The Impact of Armed Conflict on children." United Nations Children's Fund, updated, August 26, 1996, http:/ / www.unicef. org/graca/a51-306_en.pdf.

${ }^{9}$ Asung, in discussion with the author, December 11, 2013. 


\section{2 /Tiatula Ozukum}

Salesian Journal of Humanities and Social Sciences, Vol. X, No. 1. (May 2019) ISSN: 0976-1861 | DOI: 10.51818/SJHSS.10.2019.35-45 | Page: 35-45,

situation of children during armed conflict have focused primarily on their physical vulnerability. Conflict is generally understood to have a very significant psychological effect on children. "Save the Children's longstanding experience of working in humanitarian crises shows that the longer we wait for education to be resorted, the more vulnerable children become to recruitment by armed actors trafficking or other risks to their personal safety."10

In Atoizu town too, the experience of fear and anxiety as to what would happen to them next triggers certain amount of insecurity and trauma. Akaihuto, a local resident, describes one particular incident where a major firing broke out between the NSCN (I) and the NSCN (K) in the year 2006. He remembers how his siblings who were younger to him were in a state of trauma after the incident. He recollects the incident:

When the incident happened, my Mom was still at the office and my Dad had also gone out for some school related work as he was the headmaster of Adelfoes School. My younger brother and sister were at home. They must have been about 12 and 10 years then. Luckily that day my Aunt had come over to our place. Hearing the gunshots she took my siblings to my parents' room as their room was more secure than the others. They were made to lie under the bed until the situation became stable. The trauma that my siblings went through was seen later in the following days. They were not their normal self. They were not crying, they were shocked and they kept quiet for a few days. ${ }^{11}$

A parent in Atoizu narrated one of the incidents which he and his son had to face, which he felt was responsible for the kind of psychological effect it had on his son after so many years of the incident. The particular incident narrated by the parent happened in the year 2003.It was around 4 in the afternoon when all the residents of the town were doing their own household chores, and suddenly there was a burst of gunfire in the area. That day, the respondent was with his 4 year old son at home. Apparently, the

${ }^{10}$ Elin Martinez, Attacks on Education: the Impact of Conflict and Grave Violations on Children's Future, (London: Save the Children, 2013), 8.

${ }^{11}$ Akaihuto, in discussion with the author, Novomber 12, 2014. 
firing was quite severe that day and went on for more than an hour. He narrated the incident:

Since the two parties firing at each other were stationed very near to my place, it became risky for us to go out and take shelter at a more secure place. Sometimes when there is firing the houses cannot sustain bullet marks since they are mostly kaccha houses. Knowing that our house was not secure and we could not even go out to a safer place, the only thing that came to my mind was to hide my son inside the box where we store our rice and other grains at the kitchen. At the spur of the moment, I just opened the box and put my son inside the box. I instructed him to stay quiet inside the box until I come and picked him up. He did not make any sound and stayed there until I opened the box. All that while I was lying beside him outside the box. ${ }^{12}$

He further pointed out that the child is studying in Akhuluto at present (a town which is $16 \mathrm{kms}$ away from Asukhuto) as he feels the schools fare better there. The father exclaims that his son is in his $6^{\text {th }}$ standard at present, and that he was supposed to be in his $8^{\text {th }}$ standard. From the forgoing discussion, it appears that he did not fare well in his studies and his personality is very different from his other siblings as well as his classmates.

Armed conflict affects all aspects of a child growth-physical, mental and emotional. Trauma, insecurity and the consequent psychological impact have lasting adverse effect on the growth of a child. The present study also shows clearly that children are victims of these factors. The psycho-social implications on the community especially on children are vital, as any violent form of insurgency or counter insurgency measures have lasting and telling effect. Deuri argues that "the victims of various forms of aggression - war, riot, insurgency, and militancy - have often called the "third-party" as they are the silent sufferers damaged by the ravages of war. It is a group that rarely comes in focus, especially the aggressor and the defender." 13

12 (Parent), in discussion with the author, October 18, 2014.

${ }^{13}$ Deuri, Sonia Pereira, "Psycho Social Perspectives: Effects of Insurgency on Children and Women", in Insurgency and Economic Development in North East India, 


\section{4/Tiatula Ozukum}

Salesian Journal of Humanities and Social Sciences, Vol. X, No. 1. (May 2019) ISSN: 0976-1861 | DOI: 10.51818/SJHSS.10.2019.35-45 | Page: 35-45,

Section: Article

\section{Concluding Remarks}

Today's world is fraught with multiple kinds of conflicts in different national, regional and local contexts. The conflicts between and among individuals, cultures, groups, societies, and nations have different sources, stimuli, triggers and characteristics. In any single society itself we may find a variety of conflicts as well. The study finds that the immediate consequence of such kind of conflict, as it happens in other conflict zones too, is the disruption of normal life of the community. There is a general feeling of fear and mistrust among the people in Atoizu. Thus, violence in some form or the other has existed continuously in the state and in and around Atoizu leading to ineffable suffering of the community. The daily life of the community, as well as the social, economic and political activities, is affected. Besides, the frequent conflicts have disrupted various intuitions and their functioning, especially educational institutions.

Juxtaposed within the competing actors, it is thus the common people who are always at the receiving end. Consequently, as we observed from our study, conflicts adversely affect the people at varying levels and layers and none is exempted from its tentacles. One section of the society which does not escape the ravages of conflict is the children and young students. Children and youth are forced to make sacrifices when conflicts occur. Their studies take a backseat as the crisis disturbs their regular classes and studies. History of the town indicates that there have been factional clashes in the town over the decades that have adversely affected the academic life of the children. Not only the students, but teachers and parents feel the impact and constantly prepare themselves and their children to safeguard from any harm, hence, staying home becomes the best solution. That means any kind of normalcy requires more than the human power and determination.

The impact of conflict is both short-term and long term. While the issues concerning physical safety can be addressed immediately, the mental and psychological trauma that conflict inflicts on the young children linger for many years. The emotional intensity with which

ed. Paramananda Sonowal (Guwahati: OVS Publications, 2007), 96. 
Education of Children in Times of Conflict .../45

Salesian Journal of Humanities and Social Sciences, Vol. X, No. 1. (May 2019) ISSN: 0976-1861 | DOI: 10.51818/SJHSS.10.2019.35-45 | Page: 35-45,

Section: Article

the stories are narrated and recalled and the anger and frustration of the respondents of the study clearly suggest the same. For that matter, these experiences often lead them to develop a cynical and ambivalent attitude towards the 'causes' purportedly postulated by different insurgent groups. 